\title{
Latin American Microentrepreneurs: Trajectories and Meanings about Informal Work
}

\author{
Marcela Benites ${ }^{1}$, Romel Ramón González-Díaz ${ }^{2}{ }^{\mathbb{C}}$, Ángel Acevedo-Duque ${ }^{3, *}{ }^{\mathbb{C}}$, Luis Armando Becerra-Pérez ${ }^{4} \mathbb{C}$ \\ and Graciela Tristancho Cediel ${ }^{2}$
}

check for updates

Citation: Benites, M.; GonzálezDíaz, R.R.; Acevedo-Duque, Á.; Becerra-Pérez, L.A.; Tristancho Cediel, G. Latin American Microentrepreneurs: Trajectories and Meanings about Informal Work. Sustainability 2021, 13, 5449. https://doi.org/10.3390/ su13105449

\section{Academic Editors:}

Horacio Molina-Sánchez,

Gabriele Giorgi, Dante

Castillo Guajardo and

Antonio Ariza-Montes

Received: 2 April 2021

Accepted: 5 May 2021

Published: 13 May 2021

Publisher's Note: MDPI stays neutral with regard to jurisdictional claims in published maps and institutional affiliations.

Copyright: (C) 2021 by the authors. Licensee MDPI, Basel, Switzerland. This article is an open access article distributed under the terms and conditions of the Creative Commons Attribution (CC BY) license (https:/ / creativecommons.org/licenses/by/ $4.0 /)$.
1 Faculty of Social Sciences, Universidad Nacional Federico Villarreal, San Miguel 15088, Peru; abenitesm@unfv.edu.pe

2 Centro Internacional de Investigación y Desarrollo-CIID, Monteria 230001, Colombia; director@ciid.com.co (R.R.G.-D.); gracielatristancho4@gmail.com (G.T.C.)

3 Faculty of Business and Administration, Public Policy Observatory, Universidad Autónoma de Chile, Santiago 7500912, Chile

4 Faculty of Economics and Social Science, Autonomous University of Sinaloa, Sinaloa 80020, Mexico; becerra@uas.edu.mx

* Correspondence: angel.acevedo@uautonoma.cl

\begin{abstract}
Latin America has suffered for many years deep economic, political, and social problems that have led to high levels of unemployment. Therefore, microentrepreneurship has been a way out of these precarious economic systems. This research presents an interpretative hermeneutic analysis of the meaning of work for microentrepreneurs in the metropolitan region of Lima, Peru. The qualitative naturalistic methodology was used and data were obtained through 24 interviews with microentrepreneurs according to inclusion criteria such as: located in the metropolitan region of Lima (divided into 4 regions: A, B, C, and D), more than 5 years of experience, more than 25 years of age, university level of study and having had a formal job. The data were processed through ATLAS.ti9, which allowed us to analyze the discourses of the microentrepreneurs. The main findings show the following emerging categories: Motivation for entrepreneurship, Advantages of self-employment, relationship with stakeholders or interest groups, and family involvement in the business. It is concluded that Latin American microentrepreneurs associate entrepreneurship as an opportunity to improve their quality of life and establish relationships with stakeholders, with the family playing a key role in the success or failure of the business.
\end{abstract}

Keywords: microentrepreneurs; informal work; decent work; well-being at work; ODS8; sustainability, qualitative research; business reality

\section{Introduction}

By 2030, the Sustainable Development Goals enhance and promote the social, economic and political inclusion of all people, regardless of age, gender, disability, race, ethnicity, origin, religion, economic or other status [1]. This tends to promote developmentoriented policies that support productive activities, such as the creation of decent jobs, entrepreneurship, creativity, innovation and the promotion of the formalisation and growth of micro, small and medium-sized enterprises, and access to financial services, the latter being the responsibility of each nation. Latin America has been characterised as a region with political, economic and social problems that have affected entrepreneurship [1]. However, according to data provided by the studies of Ding and Li [2], this situation has worsened with the periods of mandatory social confinement, showing a $42.3 \%$ increase in the number of MSMEs (Micro, Small and Medium Enterprises) in insolvency and economic bankruptcy in 2019. On the other hand, a high level of unemployment has stimulated entrepreneurship in some economic sectors such as grocery shops with or without domicile have provided a way out of the economic crisis [3]. 
Entrepreneurship has been a factor of social change in Latin American regions. However, in other regions, such as Central Africa, it has been highlighted by the ILO's Kenya report on the "informal sector," the concept of which gave rise to intense debates on the diversity of activities without a contractual relationship in the legislative framework [4,5]. Other definitions found in the scientific literature on "atypical workers" or "atypical forms of employment" refer to different types of work modalities and even contracts, ranging from self-employment to those who enter into other types of non-labor contracts [6].

According to León Mendoza [7], informality reaches $61.2 \%$ in the world, and in East African countries such as Rwanda, it reaches 94.6\%, while in Western European countries, it is only $1.2 \%$. On the other hand, when observing the United Nations Economic Development Indicators, it is possible to infer the existence of a relationship between the presence of labor informality and economic problems. In Latin America and the Caribbean, informality is a characteristic of labor markets and reaches an average of 50\% of workers [8]. Consequently, in Peru, informal employment reaches $64.6 \%$ of workers [9]. Informality is a challenge for the public policies of any government and some of the causes are attributed to mismatches between labor demand and supply, structural investment problems, low wages, and misguided economic policies. Thus, labor informality emerges as a "refuge" sector for those who cannot find employment [10]. On the other hand, some studies reveal that there is a human need for economic independence and that life, family, or survival strategies are established in households or individuals in the face of the scarcity of salaried work, whether as a main or complementary economic activity [11].

Studies by Alzate et al. [12], López Ahumada [13], and González-Díaz et al. [14] related to entrepreneurship, informality, and subjective well-being associate the decision to undertake with the result of the cost-benefit evaluation of formal work activities, where, despite not receiving social benefits, they are confident in their managerial skills. In this sense, there are non-economic factors such as personal or family projects, satisfactions, expectations, and/or aspirations of the worker-subjects who perform them [15].

Likewise, family factors such as family history and the work history of the family of origin that can shape a certain conception of what is considered "work" and guide the choice of labor. In other words, microentrepreneurship is associated not only with economic income but also with other dimensions such as the family and the subjectivity of work [16]. It is the latter dimension that we are interested in incorporating here to find out what role it plays in this relationship. The scientific literature considers entrepreneurship only from the theories of economic development [7,9], leaving the new conceptions on the subjective well-being of human beings [14] as an opportunity to improve the theoretical understanding of the realities of microentrepreneurship in Latin America. This research focuses on the complexity of the world of work and the articulation between subjective, family, and structural factors, generating opportunities for the creation of new knowledge for the academic, scientific, and business community, as well as actions that promote the creation of public policies that benefit society and this sector. Thus, the objective is to analyze the meanings of the work of the microentrepreneur and its articulation with the family's work history as a conditioning factor of this type of insertion [17].

This research used the interpretative phenomenological method through 24 interviews with microentrepreneurs located in the metropolitan region of Lima, Peru. The results show the interpretation of microentrepreneurship, the meaning of work, and the family and labor trajectory. They show the complementarity of economic and non-economic factors in labor insertion. Specifically, self-employment constitutes a conceptual contribution that integrates the structural and subjective dimensions, which in terms of levels of analysis articulates the macro and micro social levels in the approach to the labor market, thus making the explanation more complete. Work is defined as the activity-not only economic-aimed at obtaining goods for the satisfaction of needs (not only vital but also of all kinds). We place ourselves in the perspective that considers work as a social construction, whose conceptions correspond to specific historical conditions and moments. 


\section{Background}

\subsection{Entrepreneurship in Latin America}

In the current situation, where most economies suffer from low growth rates and high levels of unemployment, designing public policies that reactivate entrepreneurship is a good option for any country [18,19]. According to Teran-Yepez and Guerrero-Mora [20], the theories of entrepreneurship that have empirical support at the global level can be divided into two: (a) those that emphasize the individual and motivational characteristics of the entrepreneur and (b) those that consider the macroeconomic environment.

In the first case, entrepreneurship is explained by pecuniary aspects that take into account the financial availability of the individual, the potential income differential perceived by the individual due to his or her conversion from employee to entrepreneur, and difficulties in the labor market such as low wages or high and persistent unemployment $[21,22]$. Other variables considered in this type of entrepreneurship are preferences for flexible hours, individual autonomy, migratory status, sex, marital status, etc. [23,24]. It is understood that it is the individual and motivational characteristics that determine whether the individual undertakes or not; these characteristics can be objective and/or subjective, ranging from tangible (money, assets, inheritances, etc.) to intangible (culture, experience, status, background, etc.).

The reasons for entrepreneurship for the second group of people (macroeconomic environment) are explained more by economic behavior and less by the individual or subjective characteristics of the entrepreneur. This current of opinion is divided into two: (1) recession-push or "shelter effect" theory and (2) pull effect or Shumpeterian theory.

In theory one, individuals undertake as a response to the difficult circumstances prevailing in the economy and labor markets [24]. Under circumstances of high unemployment in the economy, the opportunity cost of starting a business decreases, which increases the propensity to become an entrepreneur [18]. In Latin America, this mechanism is very popular, since when individuals who had been working in the government become unemployed, they immediately seek to create a "refuge" company, which usually tries to sell services to the same government. In theory two, individuals see a market opportunity that they intend to take an advantage of in the economy. In other words, entrepreneurship is associated with the dynamics of economic growth and corresponds to the entrepreneurial talent of the individual who decides to implement it [25].

In general, the two preceding theories can be simplified as necessity entrepreneurship and opportunity entrepreneurship. According to Viveros et al. [26], in the first case, these are individuals with a low socioeconomic profile, forced by the circumstances of a few or no employment opportunities and not necessarily because entrepreneurship generates a higher income than as a salaried employee. In the second case, according to these same authors, these are individuals with higher education, technical, and business training, motivated by market opportunities where their future income as entrepreneurs is higher than if they used their skills to be salaried employees.

A country's level of development can be classified according to three stages: (1) factordriven stage, (2) efficiency-driven stage, and (3) innovation-driven stage. In the first stage, countries compete with low labor costs, availability of natural resources, produce low value-added goods, have a shortage of capital, show high rates of self-employment in manufacturing activities, and have a low capacity to take advantage of innovations and exports.

In the second stage, the countries have a greater number of large companies that take advantage of economies of scale, have lower unemployment rates, have a high participation in manufacturing activities, train their workers, and adopt technologies to improve efficiency. According to Ordoñez-Gavilanes et al. [27], in this stage, entrepreneurial activity is expected to decrease as the country's development increases, given that social capital increases through private enterprise and foreign direct investment.

In the third stage, countries decrease their participation in the manufacturing industry, but greatly increase their participation in the services sector, the production of information 
technologies, telecommunications, and ways of marketing goods and doing business. At this stage, innovation promotes an increase in entrepreneurship, given the population's capacity for innovation and the intellectual and technical capital available [28,29].

According to Porter's definitions [30], most developed countries are in stage three because of their high levels of innovation, while developing countries, specifically emerging ones, are in stage two, driven by efficiency $[28,31]$. The levels of development and competitiveness observed in each country are linked to the level of entrepreneurship of that society. For example, countries with a high level of development are driven by innovation, have a high level of entrepreneurial activity, and can take advantage of the opportunities offered by the market, while countries with a low level of development are driven by efficiency, have fewer opportunities for entrepreneurship, and concentrate on salaried work [27].

Regalado et al. [28] found in a long-term analysis (25 years) done for the manufacturing industry of Baja California, Mexico, empirical evidence of a relative concentration of employed personnel in large companies and a reduction in SMEs, a situation that, in addition to the border links that impact the economy of that region, demonstrates a lower level of entrepreneurship in the SME sector.

In accordance with the pull-effect theory [32] and the innovation-driven economic development of countries, Porter [30] concludes that for this region of Mexico (applicable to other regions and countries in Latin America), it is necessary to promote a knowledgeand innovation-oriented economy that strengthens entrepreneurship and the structuring of an SME sector that can really take advantage of technological advances, knowledge, and sophistication and, in general, develop "intangible capital" that allows it to create competitive advantages.

\subsection{Decent Work as a Subjective Concept}

Job quality has been defined along three dimensions; regularity, protection and autonomy [33], which seem to be appropriate at least for the analysis of formal job quality. The definition of job quality may differ between regions and nations, as well as between individuals, and in turn may vary over time according to their age or stage of life [26,34-36]. The I.T.O. defines a quality job as one that is secure, stable, free of risk to the physical and mental health in which the worker works, performed under conditions of dignity and respect for the safety and social laws of work [37-39]. Given the precariousness, insecurity, unhealthiness and other negative conditions of work in the world and the poor quality of employment, it has defined 'decent work' as one of its doctrinal and policy priorities. This concept refers to safe work, with respect for social and protective laws for workers and their physical and psychological integrity, and has been established as a priority for its promotion and respect in the countries of the world.

\subsection{Informal Work as an Option for the Latin American Citizen}

The concept of informal work has been used in the social sciences to define different situations for 40 years $[40,41]$. The idea of grouping into one category certain economic activities related to low productivity and the poverty of those who carried them out was mainly aimed at seeking ways to improve the living conditions of this group of workers [14]. In this sense, from the beginning, the category of the informal economy was linked to the work of public policies. The study of informal work was associated with subsistence activities of those working in the marginal sectors of the economy [42], and the predominant approach was to study the informal economy in the framework of social inequality, from the point of view of gaps in employment opportunities, quality of working conditions and income from work [43]. In this perspective, the informal sector would be the result of surplus labour for employment. More recently, in the context of the complexification of the world of work and the emergence of new forms of employment and work organisation, Alejandro Portes' view of informal work has become increasingly important. This vision, unlike the one proposed by the International Labour Organisation 
(ILO), does not necessarily link informality with poverty, nor does it associate informality exclusively with urban sectors [35].

\subsection{Well-being at Work as an Assessment of Subjective Well-being}

Well-being at work is defined as a sense of vitality, interest and positive mood, and is assessed by the individual's subjective appraisal of life satisfaction and affective wellbeing $[44,45]$. It includes affective, physical, cognitive, cognitive, spiritual, social and individual processes $[46,47]$. Adequate emotional regulation at work is positively related to well-being at work [48,49]. Karreman and Vingerhoets [50] pointed out that emotional regulation functions as a mediator between attachment style and well-being. Specifically, employees in an organisation are a particularly susceptible population to stress, given current work and social conditions [51,52]. Naturally, at this stage, difficulties arise in learning the new skills and competencies required, which, added to the complications derived from a complex historical, social and economic context, could lead human talent to reduce their levels of well-being, develop depressive and/or anxious symptoms and suffer relationship difficulties [53]. This could have significant repercussions for society in economic and health terms, as it is a public health problem [54].

\subsection{SDG8 and the Latin American Microentrepreneur}

Goal 8 of the 2030 Agenda, approved by the United Nations General Assembly in September 2015, is no less ambitious than any of the others [55]. All the more so when the general framework for negotiating the agenda is taken into account. The goals were set in universal terms and therefore require compliance by both donor and recipient countries. In all cases, there are gaps to be filled and inequalities to be overcome. One of the clearest examples is the challenges of the so-called middle-income countries, where economic growth has gone hand in hand with growing inequalities [56,57]. For the purposes of this research, goal 8, which refers to economic growth and the generation of employment, and is designed to adopt global measures to improve living conditions and protect the planet in our path, did not take into consideration that a pandemic would occur during the period established for its implementation, and that as a result the goals would be affected, possibly affecting some more than others. This article presents an analysis of the fulfilment of the strategies aimed at SDG 8 "Decent work and economic growth" considering the factors of greatest impact such as unemployment, labour equality, labour formality and the contribution of the different economic sectors, including the work carried out by micro-entrepreneurs [52,58].

\section{Materials and Methods}

The qualitative research methodology recognizes the human being as a producer of knowledge, in order to understand reality through the construction of meanings, rescuing the heterogeneity of society. Its methodological structure is neither linear nor previous, it emerges in the development of the study through an inductive process, reconstructing the realities of the subjects investigated from their natural environment. For this study, Heidegger's phenomenology traces an argumentative axis towards the defense of the specific character of human reality, which makes it irreducible to categories of analysis of physical reality whose essence are objects or material things [59].

Research methodology refers simultaneously to the way in which problems are approached and answers to them are sought. In qualitative research, it is considered that reality can never be apprehended in its totality and requires the existence of a cognitive subject influenced by its cultural aspects and individual social relations, which make epistemic reality depend for its definition, understanding and analysis, on the knowledge of the ways of perceiving, thinking, feeling and acting proper to those cognitive subjects. This naturalistic qualitative research was structured following the procedure of Gonzalez-Diaz, et al. [59] who configured the hermeneutic analysis in 5 phases (see Figure 1). 


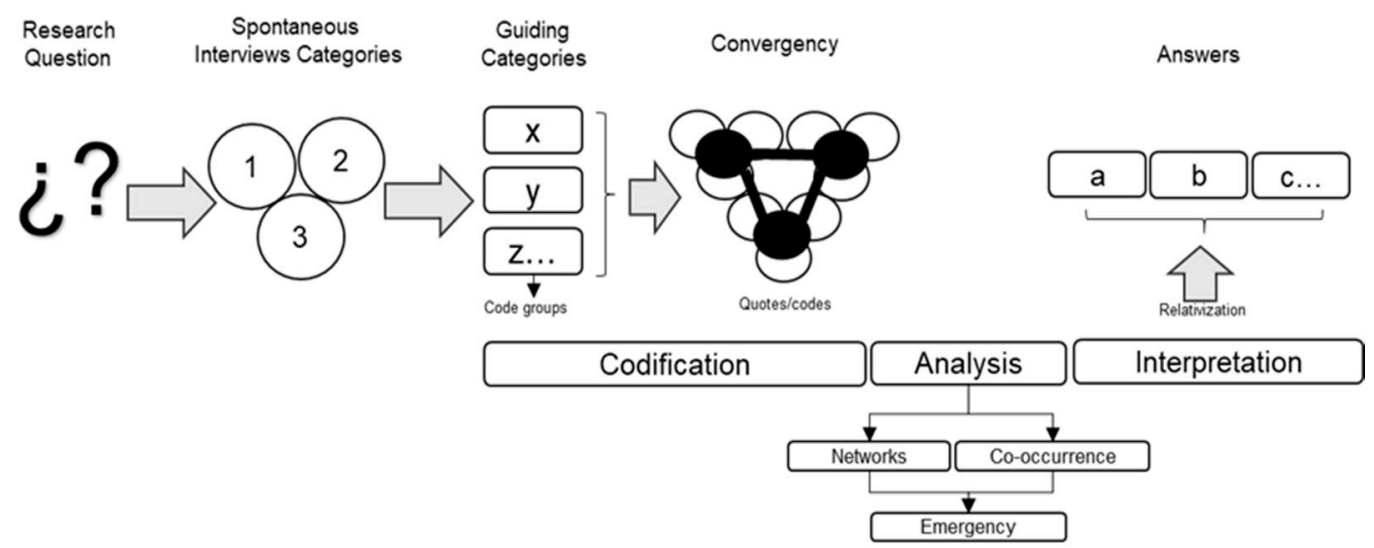

Figure 1. Hermeneutic analysis in 5 phases. Own elaboration, 2021.

Phase 1-Spontaneous Categorical Interviews (CCE) [60]: An open-ended question on the meaning of work in entrepreneurship was applied to 3 key informants selected on the basis of more than 30 years as an entrepreneur in the metropolitan region of Lima.

Phase 2-Guiding Categories: The responses of the key informants were subjected to an interpretative hermeneutic analysis and could be determined through the emergence of guiding categories and the questions for the semi-structured interview.

Phase 3-Convergence of perspectives: Once the 24 key informants were identified according to the following criteria: located in the metropolitan region of Lima, more than 5 years of experience, more than 25 years of age, university level of study and having had a formal job. The distribution of the unit of analysis was presented as follows (see Figure 2):

- Region A: It is made up of the districts in the north of Lima.

- Region B: It is made up of the districts in the south of Lima.

- Region C: It is made up of the districts in the east of Lima.

- Region D: It is made up of the districts in the center of Lima.

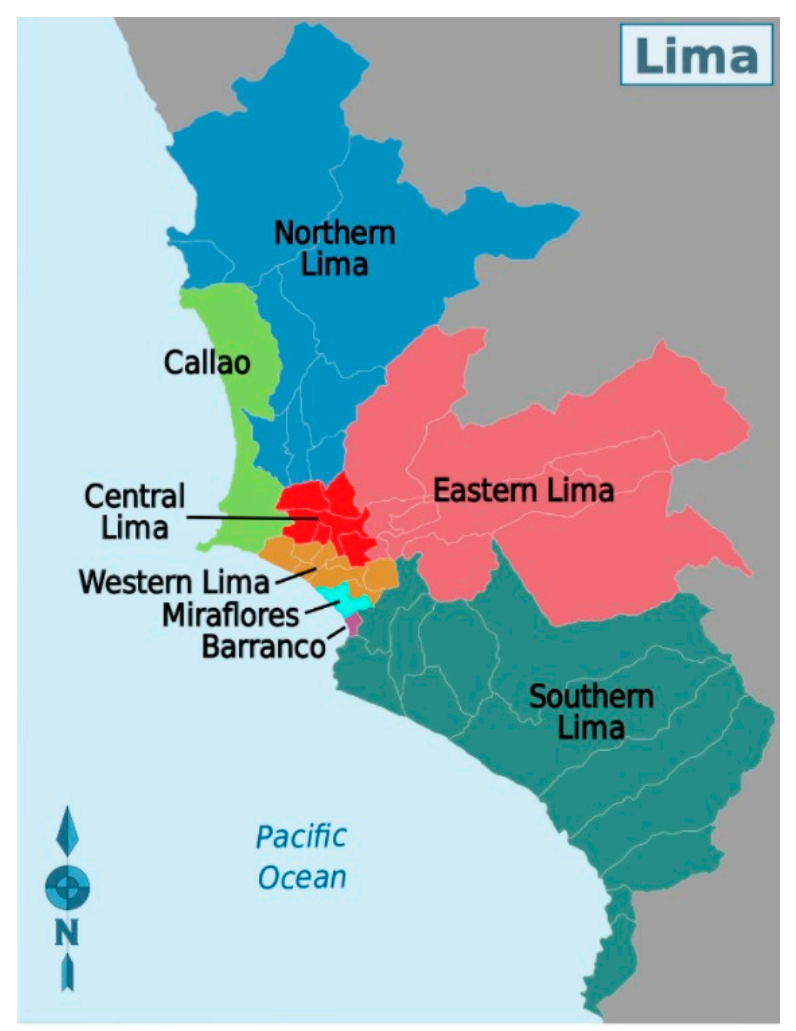

Figure 2. Distribution of the units of analysis in the metropolitan region of Lima, own elaboration, 2021. 
In red, the area of Lima Centro is shown. It is the oldest and most consolidated area of the city and where the capital began to expand, including the historic center from where the city expanded, known as the Damero de Pizarro. This area is made up of the district of Lima and other central districts, which are known as modern Lima.

In blue, they belong to Lima Norte. This zone groups together the new commercial centers of the capital. It also contains $20 \%$ of Lima's total population. It includes the northern seaside resorts, i.e., Ancón and Santa Rosa, districts in which beach houses are located, which not only are occupied in summer but also have a perennial population.

The pink-colored districts belong to Lima East. Its main road is the Carretera Central. It belongs to the suburban countryside of Lima, where there are country houses and openair restaurants, orchards and vegetable gardens. A large part of the population lives there all year round.

In steel blue, they belong to Lima Sur and balnearios. These districts contain the area of the old seaside resorts and haciendas of the south, satellite towns, human settlements, private urbanizations, beach houses, mainly occupied in summer, although they also have a stable population.

Phase 4-Coding: The responses of the key informants are coded through free codes and codes by list. Likewise, the codes are related to the guiding categories and their interrelation among them to determine the degree of rootedness and density.

Phase 5-Analysis and Interpretation: Using ATLAS.ti9 software, semantic networks are generated, code-document relationship (Sankey diagram) is drawn, the emergence index is calculated, and the information is interpreted to respond to the objective of the study.

\section{Results}

This section presents the results of the interpretative hermeneutic analysis of the interviews with microentrepreneurs in the metropolitan region of Lima. The interviews with microentrepreneurs were obtained according to inclusion criteria such as: located in the metropolitan region of Lima (divided into 4 regions: A, B, C, and D), more than 5 years of experience, more than 25 years of age (given the criteria in the requirements issued by the central bank of Peru to grant loans through its financing entities or partners "Private Bank or Public Bank"), key, university level of study, and having had a formal work. The guiding categories that emerged from the CCEs are: Microentrepreneurship, Meaning of work, Family trajectory, Career trajectory (See Figure 2).

An interpretive hermeneutical analysis of representative documents was also used, of the responses in the interviews with the microentrepreneurs, yielding an analysis of structuring, categorization, contrast, and interpretation. To do this, qualitative data analysis ATLAS.ti (version 9, Scientific Software Development GmbH, Berlin, Germany) was used as an approach that allows you to extract, categorize, and link data segments from a wide variety and volume of documents. Based on their analysis, the software helped us discover patterns [14,61] ATLAS.ti (version 9) is a qualitative data analysis (QDA) software, and its recent version is now a Windows-based application. For these authors, ATLAS.ti (version 9) provides some tools in academic research, particularly for the disciplines of the social sciences. For this work, the use of software has allowed the generation of Figures 2-5 as shown in the results section at semantic network.

Figure 2 shows the discursive proportion of the microentrepreneurs, where $52.28 \%$ concentrated their interviews in commenting on Microentrepreneurship, another 31.69\% on Meaning of work, $11.08 \%$ on Family trajectory, and $4.95 \%$ on Career trajectory. Thus, in the coding process, a series of codes emerged, which were related to the a priori categories and emerging codes through the following semantic network (see Figure 3). 


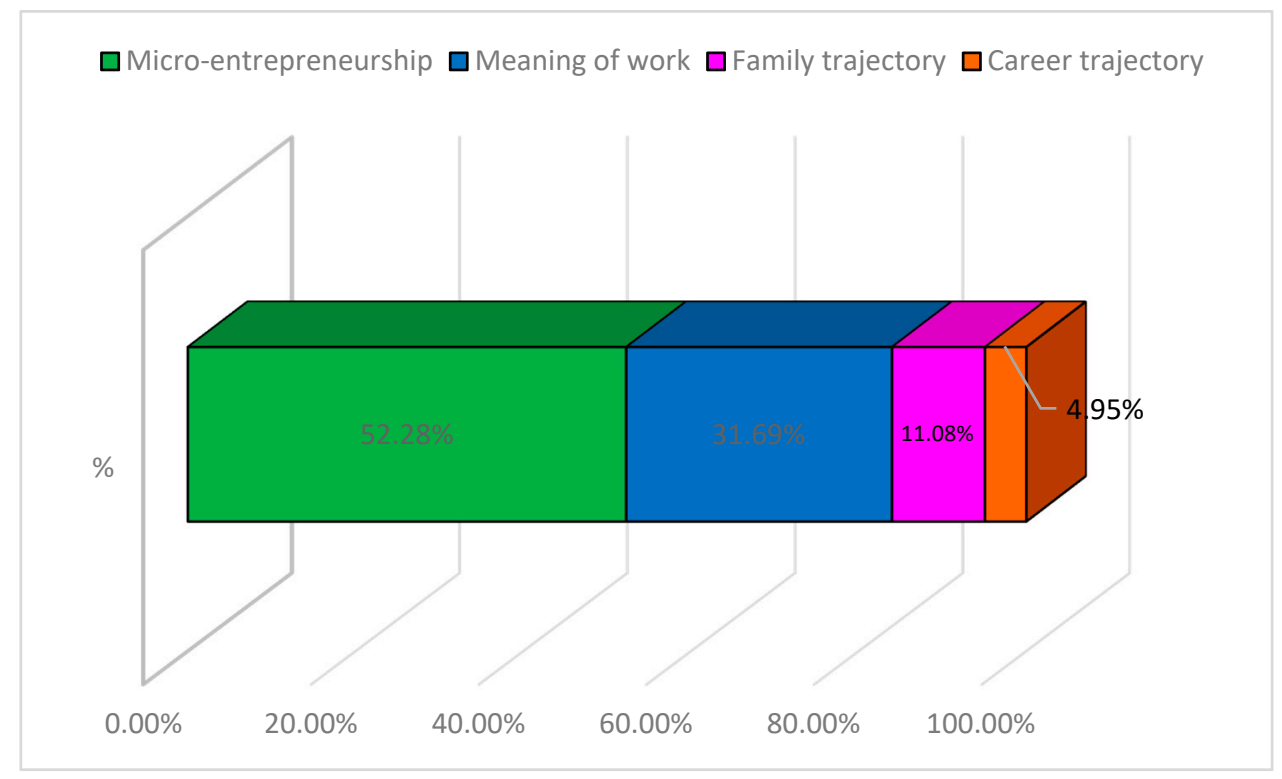

Figure 3. Microentrepreneurship, meaning of work, family trajectory, and career trajectory. Own elaboration, 2021.

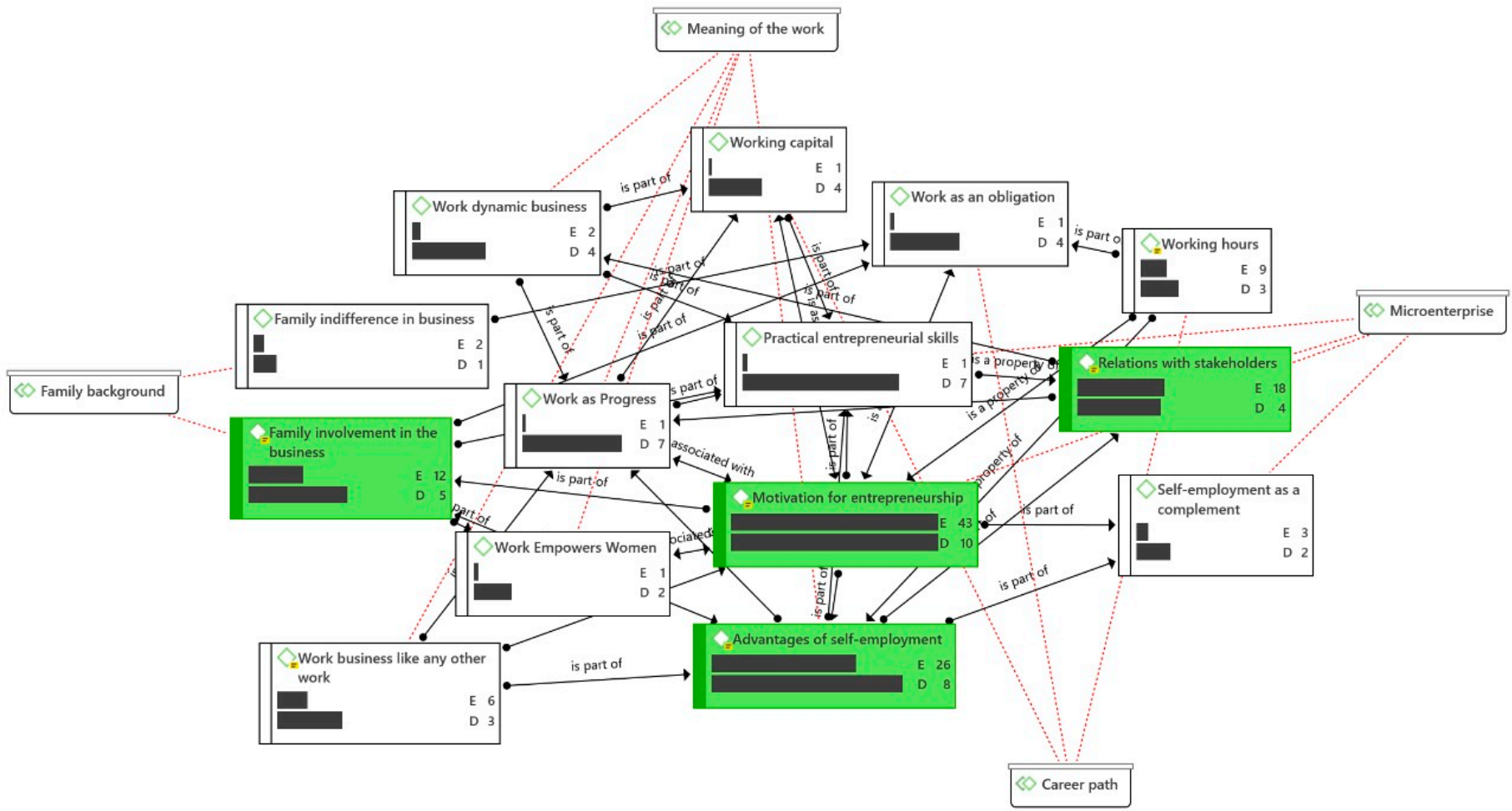

Figure 4. Aprioristic categories and emerging codes. Own elaboration, 2021.

Figure 3 refers to the construction of meanings based on the a priori categories and the discourses of the 24 key informants. The results of the emergence indexes (EDI) show the existence of ordinary codes and emergent codes. The emergent codes underlie the frequency higher than the arithmetic mean of the sum of the rootedness (E) and density (D) shown in the figure above with the green color, as follows: Motivation for entrepreneurship: $E=43$, $\mathrm{D}=10, \mathrm{IDE}=53$; Advantages of self-employment: $\mathrm{E}=26, \mathrm{D}=8, \mathrm{IDE}=34$; Relationship with stakeholders: $\mathrm{E}=18, \mathrm{D}=4, \mathrm{IDE}=22$; and Family involvement in the business: $\mathrm{E}=12$, $\mathrm{D}=5, \mathrm{IDE}=17$ (see Figure 4).

Figure 4 shows the discursive concentration through the Sankey diagram; the flow of the lines shows the width proportional to the amount of discursive flow of the microen- 
trepreneurs grouped in 4 metropolitan regions of Lima. Details of the table document with normalized values of the emerging categories among the metropolitan region of Lima are shown (see Table 1):

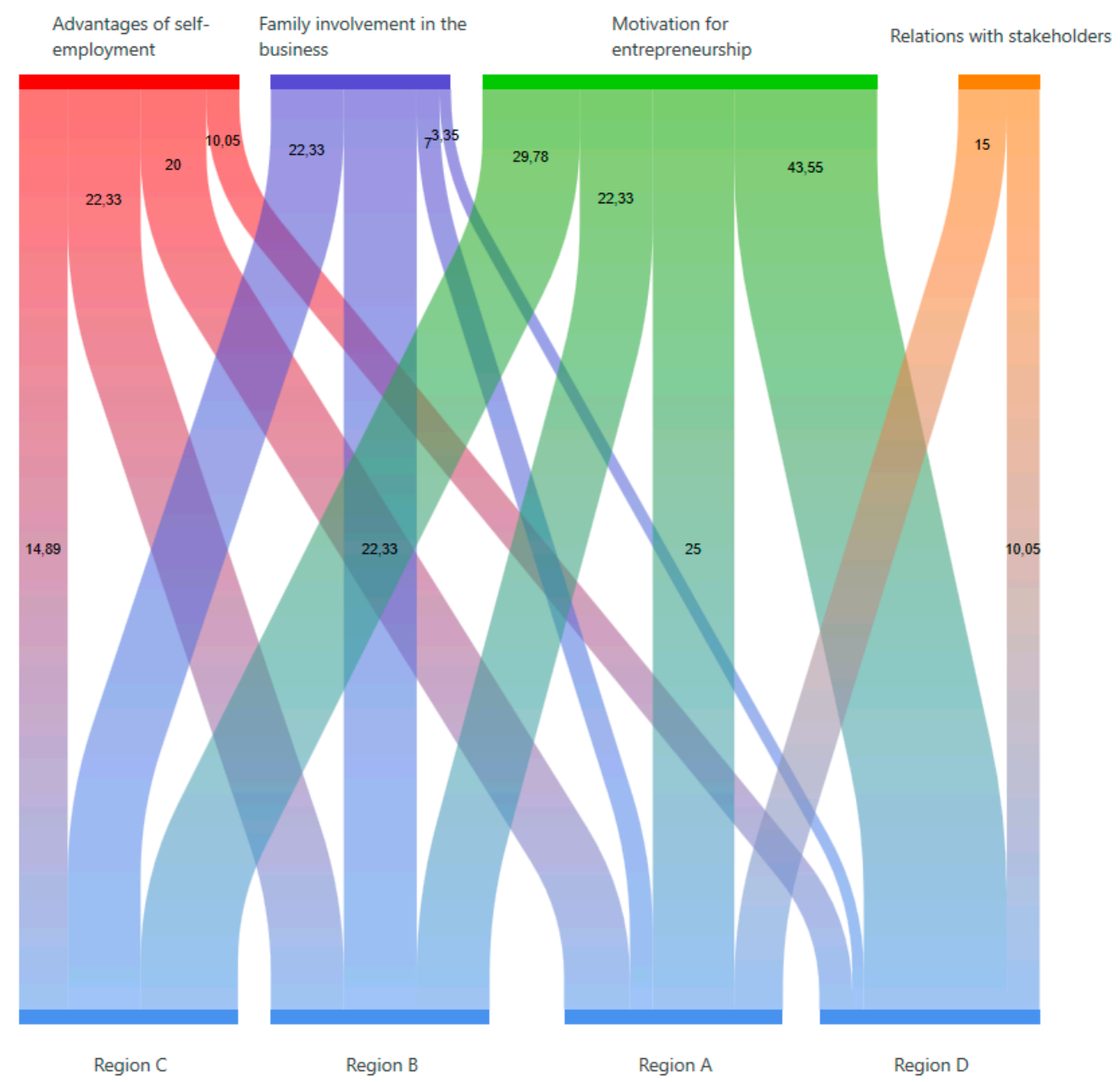

Figure 5. The results of the emergency indexes (EDI). Own elaboration, 2021.

Table 1. Emerging category vs. Lima region table. Own elaboration, 2021.

\begin{tabular}{|c|c|c|c|c|c|c|c|c|c|c|}
\hline \multirow[t]{2}{*}{ Category } & \multicolumn{2}{|c|}{$\begin{array}{c}\text { Region } A \\
\mathrm{Gr}=93 ; \mathrm{GS}=6\end{array}$} & \multicolumn{2}{|c|}{$\begin{array}{c}\text { Region } \mathrm{B} \\
\mathrm{Gr}=4 ; \mathrm{GS}=6\end{array}$} & \multicolumn{2}{|c|}{$\begin{array}{c}\text { Region } \mathrm{C} \\
\mathrm{Gr}=11 ; \mathrm{GS}=6\end{array}$} & \multicolumn{2}{|c|}{$\begin{array}{c}\text { Region D } \\
\mathrm{Gr}=24 ; \mathrm{GS}=6\end{array}$} & \multicolumn{2}{|c|}{ Total } \\
\hline & Absolute & Row & Absolute & Row & Absolute & Row & Absolute & Row & Absolute & Row \\
\hline $\begin{array}{l}\text { • Advantages of } \\
\text { self-employment } \mathrm{Gr}=26\end{array}$ & 20 & $29.73 \%$ & 22 & $33.20 \%$ & 15 & $22.13 \%$ & 10 & $14.94 \%$ & 67 & $100.00 \%$ \\
\hline $\begin{array}{c}\text { - Family involvement in the } \\
\text { business } \mathrm{Gr}=12\end{array}$ & 7 & $12.72 \%$ & 22 & $40.59 \%$ & 22 & $40.59 \%$ & 3 & $6.09 \%$ & 55 & $100.00 \%$ \\
\hline $\begin{array}{l}\text { • Motivation for } \\
\text { entrepreneurship Gr }=43\end{array}$ & 25 & $20.72 \%$ & 22 & $18.51 \%$ & 30 & $24.68 \%$ & 44 & $36.09 \%$ & 121 & $100.00 \%$ \\
\hline $\begin{array}{l}\text { - Relations with stakeholders } \\
\text { Gr }=18\end{array}$ & 15 & $59.88 \%$ & 0 & $0.00 \%$ & 0 & $0.00 \%$ & 10 & $40.12 \%$ & 25 & $100.00 \%$ \\
\hline Total & 67 & $25.00 \%$ & 67 & $25.00 \%$ & 67 & $25.00 \%$ & 67 & $25.00 \%$ & 268 & $100.00 \%$ \\
\hline
\end{tabular}

Region A: It is made up of the districts in the north of Lima.; Advantages of selfemployment $(20 ; 29.73 \%)$, Family involvement in the business $(7 ; 12.72 \%)$, Motivation for entrepreneurship (25; 20.72\%), and Relations with stakeholders $(15 ; 59.88 \%)$.

Region B: It is made up of the districts in the south of Lima.; Advantages of selfemployment $(22 ; 33.20 \%)$, Family involvement in the business $(22 ; 40.59 \%)$, Motivation for entrepreneurship $(22 ; 18.51 \%)$, and Relations with stakeholders $(0 ; 0 \%)$. 
Region C: It is made up of the districts in the east of Lima.; Advantages of selfemployment $(15 ; 22.13 \%)$, Family involvement in the business $(22 ; 40.59 \%)$, Motivation for entrepreneurship $(24.68 ; 44.44 \%)$, and Relations with stakeholders $(0 ; 0 \%)$.

Region D: It is made up of the districts in the center of Lima.; Advantages of selfemployment $(10 ; 14.94 \%)$, Family involvement in the business $(3 ; 6.09 \%)$, Motivation for entrepreneurship $(44 ; 36.09 \%)$, and Relations with stakeholders $(10 ; 40.12 \%)$

Therefore, an interpretation of the discourse is presented based on the emerging categories:

\subsection{Motivation for Entrepreneurship}

The information shows that the motivations for entrepreneurship underlie an appreciation of work as a very important aspect of a person's life, which allows him/her to develop and even, for some, brings joy to life, on the one hand, and is perceived as the only mechanism for generating income, on the other.

Finally, the interviewees work in the business is like any other job, i.e., as a salaried dependent job. It should also be noted that an important element in the motivation for entrepreneurship is to have a space in the home that can be used to develop it; this aspect facilitates the decision to start the business.

It is important to point out that the information shows that starting a business as an income-generating activity responds to a variety of motivations that go beyond the economic nature that is generally associated with it. According to the motivations found, the interviewees can be divided into two types: those who do it voluntarily and those who are forced by the circumstances of family economic pressure.

\subsection{Voluntary Entrepreneurs}

In this group are those who grew up with their family's entrepreneurship and continue with the family tradition. That is to say, they are those interviewed whose parents were dedicated to this type of work, whether as a store or business, and whom they helped since they were children when it was a store, e.g., In this way, as they say, "you stay". Those interviewed who wished to be independent decide to retire early, and with the liquidation capital, they start their own business. We also find retirees who, in order to have an activity that allows them, in addition to generating income, a distraction is important.

\subsection{Forced Entrepreneurs}

In this group, we find those whose motivation for entrepreneurship is associated with the need to generate income; those who were expelled from the labor market and who, seeing their formal job options cut short, choose to start a business in order to earn income to cover their family's expenses; those who are looking for a formal job, but cannot find a placement and have the need to generate income and with the help of their family members manage to start a business; and there are also those who assume that they do not meet the requirements of the labor market and start their business as a source of income generation, profitability, and family.

\subsection{Advantages of Self-Employment}

For the interviewees, the advantages of self-employment are associated with aspects directly linked to the business and family aspects. Advantages associated with the business:

\subsubsection{Management: These Factors Have to Do with the Administration of the Business}

The interviewees highly value being their own boss, having in their hands the freedom to make decisions about their business. They point out that in a job with a boss they have to wait for the boss's directives and are constantly under his supervision. Although they are aware that running the business is a responsibility, they do not need to be supervised. They like the autonomy and freedom in decisions to do what is best for their own work. This boss status also allows them to think about their business and future plans. 


\subsubsection{Work Organization}

One of the most frequent advantages is that the schedule is flexible, as opposed to a salaried job in which there is a start and end time. This type of activity allows you to control the work schedule and even the possibility of not working one day if you consider it necessary.

Another advantage in this aspect has to do with the ease of organizing the attention of the business with their family members, whether it is their spouse, children, or parents, to take care of the business according to their time availability. It should also be considered that this activity does not require special training, but only requires basic communication and mathematical operations skills. This advantage goes hand in hand with the fact that the business is located in the same house, which increases the probability of finding replacements.

\subsection{Profitability}

For most of the interviewees, self-employment is a job like any other in the sense that it provides income and generates profits, sometimes in a short time. Although most of the businesses started with a very few products, in a short time and with dedication, they have increased and diversified the products they offer. Although they also recognize that there are days that are good and others that are not so good, but in the end, they do generate income and perceive it as "profitable".

\subsection{Work Environment}

The work environment is defined as the space made up of the characteristics of the workplace, which, since it is located in the home, represents security, as well as comfort, since it does not require commuting, which means saving time and money to get to work, and finally, having family nearby is valued.

\subsection{Family}

Family life is one of the advantages of self-employment according to the interviewees. Some say that it allows them to share meals, to be in family company. An important aspect to highlight at this point is that for working women is that they value being close to their children, which is not possible with a paid job far from home.

\subsection{Relationship with Stakeholders or Interest Groups}

We consider that small businesses have two types of stakeholders or interest groups: internal stakeholders, such as family members who help to run the business, and external stakeholders, such as customers and suppliers. With the internal stakeholders, the family helpers, they are sure that they can count on support whenever they need it, either because they have to perform tasks related to housework, or at times previously agreed upon according to the time availability of the helpers.

With the external stakeholders, the clients constitute the main group of interest, to the point of identifying those who are from the area and those who come from farther away. They are concerned about having the products that customers request, and they are clear about the product-price relationship, i.e., they sell at prices that customers buy, because they are clear that this favors customer loyalty. In the same way, they are clear about the importance of good customer service. Some interviewees say that they enjoy customer service very much, because they establish pleasant relationships, which they attribute to their charisma, good treatment, and patience as they talk about their problems or about national or world events. An important element is the trust with the client, which is developed with the constant treatment that culminates in obtaining credit when they request it, differentiating between those who pay daily, weekly, and monthly. 


\subsection{Family Participation in the Business}

This type of enterprise allows family participation in the business, hence most of them are family businesses. The interviewees tell how the coordination among the members who help in the business is carried out. Responsibilities and schedules are distributed, even when unforeseen events arise, there is quick coordination, they are solved, and the business continues to operate.

The worker's concern for the family stands out, especially for the children, especially when they are small. In the narratives of the interviewees who had a salaried job, the importance for them of working close to their children stands out, since they quit those jobs and started the small business that allows them to be close to their children.

In summary, the narratives of the interviewees show us that several factors of diverse but closely linked nature converge in the entrepreneurial decisions, such as the advantages offered, the relationship with stakeholders, and the participation or role of the family.

\section{Discussion}

In this broad sense, and as a first approach to the phenomenon under study, it is necessary to determine how microentrepreneurs or entrepreneurs have become aware of their trajectories in the motivation to undertake and the meanings about informal work [62] and demonstrated trajectory in the organization of work and that there is in some way or another a subjective well-being in the entrepreneurial activity, as well as to recognize what have been the motivations to belong to this type of companies, being the objective ones, the family participation in the business. (what are their interests, actions, and impacts on the sectors of interest) [63].

In the last three decades, interest has grown in the advantages of self-employment, calling for the implementation of national and international public policies that recognise micro-enterprises based on the consideration that they are decisive for the generation of employment and local development [64]. In this sense, for authors such as Kuratko et al. [62], the main findings reveal the motivations for entrepreneurship of Latin Americans, who are not only motivated by the economic situation in the region, but also by personal growth [65], who value the advantages of self-employment.

In principle, self-employment associated with entrepreneurship is considered an arduous task where studies reveal that $92.4 \%$ fail in the first year [57]. Self-employment is considered in Latin America as an option. However, to be successful, family support is required to provide continuous motivation and mitigate the demotivations of this challenge. These results coincide with Riolfo [65], who states that, in terms of the study needs of microenterprises, it is clear that there is still a lot of research to be done. In this sense, different authors consider relevant the need for more research of both an empirical and theoretical nature, in which data collection is treated with special care [36]. On the other hand, authors such as Hörisch [66] and Rela et al. [67] express their concern about the need for a greater degree of conceptual rigour on the meaning of work, since Latin Americans' perceptions are associated with subjective well-being or the good life. Thus, together with interdisciplinary approaches, understanding and explanation in this field could point to a more sustainable economy and management of the common good.

From this perspective, the approaches used showed that this conglomerate of information comes from different disciplines and approaches the topic in different ways in the business world [68]. However, none of these approaches manages to fully capture the notion of what a microentrepreneurship is nor the complexity of its socio-economic dynamics, but each provides elements that help to identify it, while serving as tools to analyze and study the characteristics and forms of survival of this sector [57]. This means that research into culture in entrepreneurship must take into account its contributions and shortcomings, also considering the importance of the socio-cultural contexts in which this activity is generated, and the different types of microenterprises that are developed in Latin America [52,69], in search of rapid growth for the benefit not only of entrepreneurs but also of the society for which their goods and services are intended [70-73]. 
Consequently, and taking into account the complementarity of economic and noneconomic factors in labor insertion [46], specifically self-employment, it constitutes a conceptual contribution that integrates the structural and subjective dimensions, which in terms of levels of analysis articulates the macro and micro social levels in the approach to the labor market, thus making the explanation more complete. For Dias et al. [3], trying to place microenterprises in the formal or informal sector, in the urban or agrarian space, by a particular type of economic activity, or through gender relations is tantamount to denying that these are heterogeneous, diversified, and fragmented labor markets in which determining through a single criterion implies not recognizing that these are spaces under construction characterized by their often-vague boundaries.

Finally, it is evident that under this broad heading the problem of managing explicit information on microentrepreneurs in Latin America with a track record in welfare management on informal labor is complex to explain at this point [42,74,75]. However, it is important to remember that enterprises are heterogeneous, so that trying to classify them on the basis of their size is not easy, although it is necessary for institutions wishing to establish support programs and for researchers who intend to study them.

\section{Conclusions}

It is concluded that Latin American microentrepreneurs associate entrepreneurship as an opportunity to improve their quality of life and establish relationships with stakeholders, with the family playing a key role in the success or failure of the business. Promoting emerging codes such as motivation for entrepreneurship, forced entrepreneurship, profitability, among others. By virtue of these significant findings, contributions are made to the theoretical gap in terms of the meaning of work and the perception of Latin American microentrepreneurship. The results of this research show the economic value acquired by aspects related to the human being towards sustainability in this type of business, such as: motivation for entrepreneurship, family involvement in the business, management, the relationship with stakeholders, voluntary entrepreneurs, forced entrepreneurs, the work environment, profitability, technological skills, education, the advantages of independent work, and information management, all in adverse scenarios that impose strong financial, technological, and market restrictions, such as the one being experienced in these four regions of Lima.

Therefore, the contribution of scientific and technological research is necessary as a priority factor to promote sustainable entrepreneurship, creativity, innovation, and the generation of new concepts. This research contributes to promoting public policies in favor of this vulnerable sector, with a broad vision of opportunities framed in Sustainable Development Goal 8 (SDG8), which promotes inclusive and sustainable economic growth, full and productive employment, and decent work for all those who make a living in microenterprises. To this end, we must work to improve productivity levels and reduce the competitiveness gap that is so marked in Latin American countries, expand the productive supply of the Peruvian market, improve the levels of tax legality so that microentrepreneurs recognize the safe path to growth, and sustainability of their productive units in their business.

Author Contributions: Conceptualization, M.B., R.R.G.-D., Á.A.-D. and L.A.B.-P.; data curation, Á.A.-D; formal analysis, R.R.G.-D. and Á.A.-D.; funding acquisition, M.B., Á.A.-D. and G.T.C.; methodology, M.B., R.R.G.-D. and Á.A.-D.; project administration, Á.A.-D.; resources, Á.A.-D.; supervision, R.R.G.-D., Á.A.-D. and L.A.B.-P.; validation, M.B., R.R.G.-D., Á.A.-D. and G.T.C.; writingoriginal draft, Á.A.-D.; writing - review and editing, Á.A.-D. All authors have read and agreed to the published version of the manuscript.

Funding: The APC was partially funded by the Centro Internacional de Investigación y DesarrolloCIID.

Institutional Review Board Statement: Not applicable.

Informed Consent Statement: Not applicable. 
Data Availability Statement: Data are available on request from the authors.

Conflicts of Interest: The authors declare no conflict of interest.

\section{References}

1. Toscano-Hernández, A. Análisis y evaluación de la Sostenibilidad Empresarial: Herramientas de apoyo a la toma de decisiones y la medición del rendimiento en pymes. Sustainability 2020.

2. Ding, A.W.; Li, S. National response strategies and marketing innovations during the COVID-19 pandemic. Bus. Horiz. 2021, 64, 295-306. [CrossRef] [PubMed]

3. Dias, Á.L.; Manuel, E.C.; Dutschke, G.; Pereira, R.; Pereira, L. Economic crisis effects on SME dynamic capabilities. Int. J. Learn. Chang. 2021, 13, 63. [CrossRef]

4. Chatterjee, S.; Lebesmuehlbacher, T.; Narayanan, A. How productive is public investment? Evidence from formal and informal production in India. J. Dev. Econ. 2021, 151, 102625. [CrossRef]

5. Ramoni-Perazzi, J.; Orlandoni-Merli, G. Analysis of the Formal/Informal Wage Inequalities in Colombia: A Semiparametric Approach. J. Appl. Soc. Sci. 2021, 15, 107-131. [CrossRef]

6. Negrete Prieto, R.; Ramírez Reynoso, T. Resolución I de la XIX Conferencia Internacional de Estadísticos del Trabajo y su impacto en la estadística laboral en México. Real. Datos Espacio. Rev. Int. Estadística Geogr. 2015, 6, 92-131.

7. León Mendoza, J.C. Determinantes de la informalidad laboral a nivel de los 24 departamentos peruanos: 2010-2018. Ph.D. Thesis, Faculty of Economic and Administrative Sciences, National University of Callao, Bellavista, Peru, 2020. Available online: https:/ / bit.ly/3w9pzCY (accessed on 16 February 2021).

8. Pabón, M.V.R. La informalidad laboral en América Latina. Arch. Rev. Cult. Nuestra Am. 2018, 25, $18-67$.

9. Aliaga Huaynalaya, J.P. Inflación y el crecimiento económico: Determinantes del desempleo en el Perú en los años 1980-2015. 2018. Available online: https:/ / repositorio.continental.edu.pe/handle/20.500.12394/4906 (accessed on 13 February 2021).

10. Marzi Muñoz, D.B.; Ugarte Cataldo, J.L. Focus America Latina. Latinoamérica y la OIT: El mínimo como máximo. Lav. Dirit. 2019, 33, 481-498.

11. Caminos, J. Análisis del teletrabajo y su recepción legislativa en latinoamérica. Revista Jurídica Trab. 2020, 1, $209-237$.

12. Alzate, Y.M.S.; Zapata, G.M.V.; Gómez, M.J.B. Un análisis de los estudios acerca de las memorias de sostenibilidad en Latinoamérica. Contab. Neg. 2018, 13, 56-73. [CrossRef]

13. López Ahumada, J.E. Trabajo decente y globalización en Latinoamérica: Una alternativa a la desigualdad laboral y social. Doc. Trab. 2017, 98, 1-50.

14. González-Díaz, R.; Acevedo-Duque, Á.; Salazar-Sepúlveda, G.; Castillo, D. Contributions of Subjective Well-Being and Good Living to the Contemporary Development of the Notion of Sustainable Human Development. Sustainability 2021, $13,3298$. [CrossRef]

15. Yi, H.-T.; Amenuvor, F.E.; Boateng, H. The Impact of Entrepreneurial Orientation on New Product Creativity, Competi-tive Advantage and New Product Performance in SMEs: The Moderating Role of Corporate Life Cycle. Sustainability 2021, 13, 3586. [CrossRef]

16. Ceular-Villamandos, N.; Navajas-Romero, V.; Caridad y López del Río, L.; Zambrano-Santos, L.Z. Workplace Situation and Well-Being of Ecuadorian Self-Employed. Sustainability 2021, 13, 1892. [CrossRef]

17. Han, H.; Quan, W.; Al-Ansi, A.; Chung, H.; Ngah, A.; Ariza-Montes, A.; Vega-Muñoz, A. A Theoretical Framework Development for Hotel Employee Turnover: Linking Trust in Supports, Emotional Exhaustion, Depersonalization, and Reduced Personal Accomplishment at Workplace. Sustainability 2020, 12, 8065. [CrossRef]

18. Bustillos Bailey, A.; Sánchez Nogales, C.; López Murillo, S.; Campana Arroyo, G. Entre el emprendedurismo y la sub-sistencia. Rev. Investig. Neg. 2020, 13, 112-121. [CrossRef]

19. González-Díaz, R.R.; Cruz-Ayala, K. Contraloría financiera en la contratación pública. Una revisión de los contratos de obras públicas del estado Venezolano. Inquietud Empresarial 2020, 20, 43-58.

20. Teran-Yepez, E.; Guerrero-Mora, A.M. Teorías de emprendimiento: Revisión crítica de la literatura y sugerencias para futuras investigaciones. Rev. Espac. 2020, 41, 7.

21. Sumba-Bustamante, R.Y.; Saltos-Ruiz, G.R.; Rodríguez-Suarez, C.A.; Tumbaco-Santiana, Z.L. El desempleo en el ecuador: Causas y consecuencias. Polo Conocimiento 2020, 5, 774-797.

22. Bergel, S.D. Desarrollo sustentable y medio ambiente: La perspectiva latinoamericana. Alegatos 2020, 1, $196-221$.

23. Alonso, R.G.; Thoene, U.; Figueroa, A.M.; Amaris, E.M. El Emprendimiento Social en el marco de la Alianza del Pacífico. Revesco. Rev. Estud. Coop. 2020, 133, 67341. [CrossRef]

24. Valenzuela-Klagges, I.; Valenzuela_Klagges, B.; Irarrazaval, J. Desarrollo Emprendedor Latinoamericano y sus Deter-minantes: Evidencias y Desafíos. Rev. Pilquen. Sección Cienc. Soc. 2018, 21, 55-63.

25. Camarillo, A.B. La Nueva Forma de Hacer Negocios, un Comparativo de la Cultura del Emprendimiento Entre México y Perú. Vida Hist. 2019, 90-97. [CrossRef]

26. Viveros, J.M.A.; Pisso, F.M.; Barajas, D.C. Emprendimientos radicalmente sustentables: Diseños emergentes desde el pensamiento crítico. Kepes 2020, 17, 493-536.

27. Ordoñez-Gavilanes, M.E.; Rodríguez-Pillaga, R.T.; Ordóñez-Espinoza, C.G. Reflexiones sobre emprendimiento co-munitario y desarrollo local. Dominio Cienc. 2020, 6, 121-139. 
28. Regalado, V.B.; López, N.T.M.; González-Díaz, R.R.; Polo, E.A.S. Innovación y Desempeño Económico en México. CIID J. 2020, 1 , 80-102. [CrossRef]

29. Dagnino, R.P. Innovación y desarrollo social: Un desafío latinoamericano. Rev. Eletrôn. Adm. 2001, 7,6.

30. Porter, M.E. Michael Porter on competition. Antitrust Bull. 1999, 44, 841.

31. González-Díaz, R.R.; Polo, E.A.S. Estrategias gerenciales para la innovación en instituciones educativa públicas. J. Latin Am. Sci. 2017, 1, 1-23.

32. Carree, M.; Thurik, R. The Effect of Entrepreneurial Activity on National Economic Growth. Small Bus. Econ. 2005, 24, 311-321. [CrossRef]

33. Zugravu-Soilita, N.; Kafrouni, R.; Bouard, S.; Apithy, L. Do cultural capital and social capital matter for economic performance? An empirical investigation of tribal agriculture in New Caledonia. Ecol. Econ. 2021, 182, 106933. [CrossRef]

34. Robert, K.W.; Parris, T.M.; Leiserowitz, A.A. What is Sustainable Development? Goals, Indicators, Values, and Practice. Environ. Sci. Policy Sustain. Dev. 2005, 47, 8-21. [CrossRef]

35. González-Díaz, R.R.; Ledesma, K.N.F. Cultura organizacional y Sustentabilidad empresarial en las Pymes durante crisis periodos de confinamiento social. CIID J. 2020, 1, 28-41. [CrossRef]

36. Saiz-Álvarez, J.M.; Vega-Muñoz, A.; Acevedo-Duque, Á.; Castillo, D. B Corps: A Socioeconomic Approach for the COVID-19 Post-crisis. Front. Psychol. 2020, 11, 1867. [CrossRef] [PubMed]

37. Atitsogbe, K.A.; Kossi, E.Y.; Pari, P.; Rossier, J. Decent Work in Sub-Saharan Africa: An Application of Psychology of Working Theory in a Sample of Togolese Primary School Teachers. J. Career Assess. 2021, 29, 36-53. [CrossRef]

38. Noroño Sánchez, J.; Nuñez Villavicencio, M.; González Díaz, R. Ética sindical como mecanismo impulsor de competitividad en las pequeñas y medianas empresas./Union ethics as a mechanism driving competitiveness in small and medium-sized enterprises. Utop. Prax. Latinoam. 2020, 25, 154-173. [CrossRef]

39. Ledesma, K.N.F.; González-Díaz, R.R. Etica sindical en la negociación de contrato colectivo de construcción de obras públicas. Caso Ducolsa. CIID J. 2020, 1, 1-14. [CrossRef]

40. Hamia, M.A.A. Are developing countries accumulating sufficient total factor productivity to sustain their economic growth and job creation? Empirical evidence from the Middle East and North Africa region. Rev. Dev. Econ. 2020, 24, 1102-1127. [CrossRef]

41. Bustamante-Cabrera, G.Í.; González-Díaz, R.R. Times of pandemic in Bolivia: Role of political and social organization in health policy. Eur. J. Mol. Clin. Med. 2021, 8, 2295-2304. Available online: https://ejmcm.com/article_8137.html (accessed on 10 May 2021).

42. Vimal, K.E.K.; Kandasamy, J.; Duque, Á.A. Integrating sustainability and remanufacturing strategies by remanufacturing quality function deployment (RQFD). Environ. Dev. Sustain. 2021, 1-33. [CrossRef]

43. Guirado, C.; Valldeperas, N.; Tulla, A.F.; Sendra, L.; Badia, A.; Evard, C.; Cebollada, À.; Espluga, J.; Pallarès, I.; Vera, A. Social farming in Catalonia: Rural local development, employment opportunities and empowerment for people at risk of social exclusion. J. Rural. Stud. 2017, 56, 180-197. [CrossRef]

44. Jovanović, V. A bifactor model of subjective well-being: A re-examination of the structure of subjective well-being. Pers. Individ. Differ. 2015, 87, 45-49. [CrossRef]

45. Contreras-Barraza, N.; Espinosa-Cristia, J.F.; Salazar-Sepulveda, G.; Vega-Muñoz, A.; Ariza-Montes, A. A Scientometric Systematic Review of Entrepreneurial Wellbeing Knowledge Production. Front. Psychol. 2021, 12, 641465. [CrossRef]

46. Joshanloo, M. Investigating the relationships between subjective well-being and psychological well-being over two decades. Emotion 2019, 19, 183-187. [CrossRef] [PubMed]

47. Colovic, A.; Williams, C. Group culture, gender diversity and organizational innovativeness: Evidence from Serbia. J. Bus. Res. 2020, 110, 282-291. [CrossRef]

48. Lavy, S.; Littman-Ovadia, H. All you need is love? Strengths mediate the negative associations between attachment orientations and life satisfaction. Pers. Individ. Differ. 2011, 50, 1050-1055. [CrossRef]

49. Stevenson, J.C.; Millings, A.; Emerson, L.-M. Psychological Well-being and Coping: The Predictive Value of Adult Attachment, Dispositional Mindfulness, and Emotion Regulation. Mindfulness 2018, 10, 256-271. [CrossRef]

50. Karreman, A.; Vingerhoets, A.J. Attachment and well-being: The mediating role of emotion regulation and resilience. Pers. Individ. Differ. 2012, 53, 821-826. [CrossRef]

51. Colovic, A.; Escobar, O.R.; LaMotte, O.; Meschi, P.-X. Multinational enterprises, local firms, and employee human rights violation in the workplace. Multinatl. Bus. Rev. 2019, 27, 247-265. [CrossRef]

52. González-Díaz, R.R.; Becerra-Perez, L.A. Stimulating Components for Business Development in Latin American SMEs. In Advances in Intelligent Systems and Computing; Springer Science and Business Media LLC: Secaucus, NJ, USA, 2021 ; pp. 366-374.

53. Cantazaro, A.; Wei, M. Adult Attachment, Dependence, Self-Criticism, and Depressive Symptoms: A Test of a Mediational Model. J. Pers. 2010, 78, 1135-1162. [CrossRef]

54. Brenner, S.L.; Burns, B.J.; Curry, J.F.; Silva, S.G.; Kratochvil, C.J.; Domino, M.E. Mental health service use among adolescents following participation in a randomized clinical trial for depression. J. Clin. Child Adolesc. Psychol. 2015, 44, 551-558. [CrossRef]

55. Ullah, F.; Wu, Y.; Mehmood, K.; Jabeen, F.; Iftikhar, Y.; Acevedo-Duque, Á.; Kwan, H. Impact of Spectators' Perceptions of Corporate Social Responsibility on Regional Attachment in Sports: Three-Wave Indirect Effects of Spectators' Pride and Team Identification. Sustainability 2021, 13, 597. [CrossRef] 
56. Colovic, A.; Schruoffeneger, M. Entrepreneuring for deprived urban communities: Exploring the role of micro-entrepreneurship. Eur. Manag. Rev. 2021. [CrossRef]

57. González-Díaz, R.R.; Acevedo-Duque, Á.E.; Guanilo-Gómez, S.L.; Cachicatari-Vargas, E. Business counterintelligence as a protection strategy for SMEs. Entrep. Sustain. Issues 2021, 8, 340-352. [CrossRef]

58. González-Díaz, R.R.; Acosta-Moltó, E.M. ExPro as psycho-affective stimulators through experiential marketing in nonprofit organizations. CIID J. 2020, 1, 1-27. [CrossRef]

59. González-Díaz, R.R.; Acevedo-Duque, Á.; Guanilo-Gómez, S.; Cruz-Ayala, K. Ruta de Investigación Cualitativa-Naturalista. Una alternativa para estudios gerenciales. Rev. Cienc. Soc. 2021, 28, 34-52. [CrossRef]

60. Gonzalez-Diaz, R.R.; Polo, E.A.S. Entrevistas Espontaneas Categoriales (EEC) para la construcción de categorías orientadoras en la investigación cualitativa. J. Latin Am. Sci. 2020, 2, 1-11. Available online: https://lasjournal.com/index.php/abstract/article/ view / 2 (accessed on 10 May 2021).

61. Hwang, S. Utilizing Qualitative Data Analysis Software. Soc. Sci. Comput. Rev. 2007, 26, 519-527. [CrossRef]

62. Kuratko, D.F.; McMullen, J.S.; Hornsby, J.S.; Jackson, C. Is your organization conducive to the continuous creation of social value? Toward a social corporate entrepreneurship scale. Bus. Horiz. 2017, 60, 271-283. [CrossRef]

63. Huerta, G. El Cuarto Sector de la Economía en Chile. Es Necesaria una Legislación Para las Empresas B. Master's Thesis, University of Chile, Santiago, Chile, 2018. Available online: http://repositorio.uchile.cl/handle/2250/151833 (accessed on 10 May 2021).

64. Hsu, F.-J.; Chen, S.-H. Does corporate social responsibility drive better performance by adopting IFRS? Evidence from emerging market. J. Comput. Appl. Math. 2020, 371, 112631. [CrossRef]

65. Riolfo, G. The New Italian Benefit Corporation. Eur. Bus. Organ. Law Rev. 2020, 21, 279-317. [CrossRef]

66. Hörisch, J. The relation of COVID-19 to the UN sustainable development goals: Implications for sustainability accounting, management and policy research. Sustain. Account. Manag. Policy J. 2021. ahead-of-p. [CrossRef]

67. Rela, I.Z.; Awang, A.H.; Ramli, Z.; Rusdan, M.; Mappasomba, M.; Nikoyan, A. Conceptual model of corporate social responsibility impact on community well-being. Entrep. Sustain. Issues 2020, 8, 311-323. [CrossRef]

68. Stuetzer, M.; Audretsch, D.B.; Obschonka, M.; Gosling, S.D.; Rentfrow, P.J.; Potter, J. Entrepreneurship culture, knowledge spillovers and the growth of regions. Reg. Stud. 2017, 52, 608-618. [CrossRef]

69. Bianchi, C.; Reyes, V.; Devenin, V. Consumer motivations to purchase from benefit corporations (B Corps). Corp. Soc. Responsib. Environ. Manag. 2020, 27, 1445-1453. [CrossRef]

70. Grabowski, W.; Stawasz, E. The Role of Business Consulting in Creating Knowledge and Formulating a Strategy of Development in Polish Micro-Enterprises. J. East Eur. Manag. Stud. 2017, 22, 374-396. [CrossRef]

71. González-Díaz, R.R.; Lara, R.J.V.; López, R.O.; Hernández-Royett, J. Tax on advertising and commercial advertising: An analysis from Municipal Tax Management. Globalciencia 2016, 2, 20-34.

72. González-Díaz, R.R.; Perez, L.A.B. Análisis financiero empresarial del sector comercio como factor de competitividad través de la lógica difusa. Estrategia 2015, 1, 1-10.

73. González-Díaz, R.R.; Acevedo-Duque, Á.; Flores-Ledesma, K.N.; Cruz-Ayala, K.; Guanilo Gomez, S.L. Knowledge Management Strategies Through Educational Digital Platforms During Periods of Social Confinement. In Trends and Applications in Information Systems and Technologies; Rocha, A., Adeli, H., Dzemyda, G., Moreira, F., Ramalho Correia, A.M., Eds.; Springer International Publishing: Cham, Switzerland, 2021; Volume 2, pp. 297-303.

74. Hernández-Julio, Y.F.; Meriño-Fuentes, I.; González-Díaz, R.R.; Guerrero-Avendaño, A.; Toledo, L.V.O.; Bernal, W.N. Fuzzy knowledge discovery and decision-making through clustering and Dynamic tables: Application in Colombian business Finance. In Proceedings of the 15th Iberian Conference on Information Systems and Technologies (CISTI), Sevilla, Spain, 24-27 June 2020; pp. 1-5. [CrossRef]

75. González-Díaz, R.R.; Vásquez Llamo, C.E.; Hurtado Tiza, D.R.; Menacho Rivera, A.S. Plataformas interactivas y estrategias de gestión del conocimiento durante el Covid-19. Rev. Venez. Gerencia 2020, 25, 68-81. Available online: https:// produccioncientificaluz.org/index.php/rvg/article/view/35177 (accessed on 10 May 2021). 